\title{
Real time stochastic simulator of the electrical power produced by a photovoltaic power system
}

\author{
V. Autier, V. Molcrette, H. Roisse, J-L. Kotny \\ Laboratoire Systèmes Electrotechniques et Environnement \\ L.S.E.E., Faculté des Sciences Appliquées \\ Technoparc Futura, 62400 Béthune (France) \\ Phone : (33)321-637-215, fax: (33)321-637-211, e-mail: vincent.autier@fsa.univ-artois.fr
}

\begin{abstract}
The aim of this paper is to build an understanding concepts of creation of a stochastic generator of the electrical power delivered by the PV array. Much attention is paid to help fitters to get simply and rapidly simulations of scenarios of the electrical power. The developed generator integrated the effect of the clouds layers by 3 SKY-index which are computed by a statistical approach. The irradiance collected by the PV panels, is deduced from an analytical expression of the theoretical irradiance (without clouds) and the SKY-index. The used databases are provided from the 'European daylight and solar radiation database Satel-light', assembled for the period 19962000.
\end{abstract}

\section{Keys words}

Photovoltaic, PV module, electrical network, irradiance.

\section{Introduction}

These last years the electrical energy, produced by photovoltaic power systems, increase more and more consecutively of the kioto agreement. So,the managers of the electrical networks, are more and more confronted to the problems related to their integration. In effect, the electrical networks are not designed to connect such sources of energy. Research centers such as the CNRT develop solutions making possible the adaptation of those existing electrical networks in presence of these decentralized productions. Statistical approaches of evaluation of the defects are often adopted. They simulate a great number of credible scenarios of load flow and compute the average annual duration of shutdowns. It is for this kind of studies that real time stochastic simulator has been developed. The scenarios generated by this simulator are obtained from data provided from irradiance data bases for the considered geographic point. This data have been collected through the last ten years.

\section{Electrical power expression in function of the global irradiance}

Figure 1 represents a traditional characteristic IV of a photovoltaic module for an operating temperature of $30^{\circ} \mathrm{C}$.

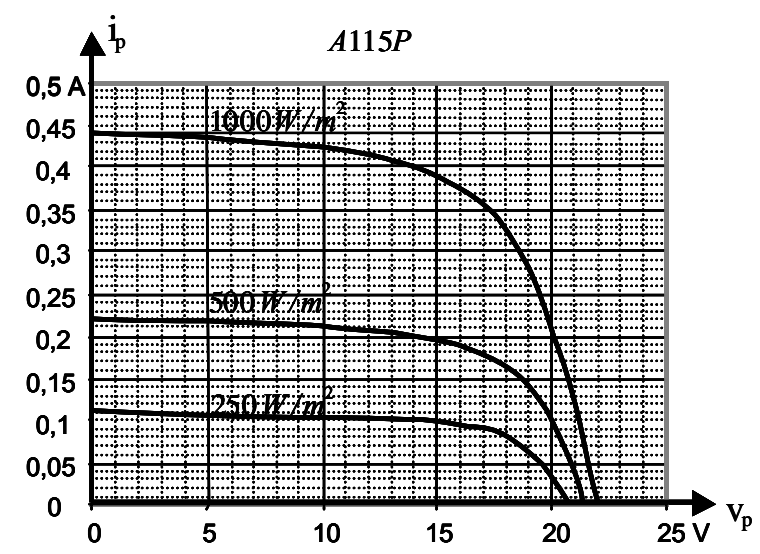

Fig. 1. IV characteristic of a PV panel manufactured by the firm free energy europe

This type of characteristic can be modelled [1],[2] in static mode by an electrical equivalent circuit as shown in figure 2 .

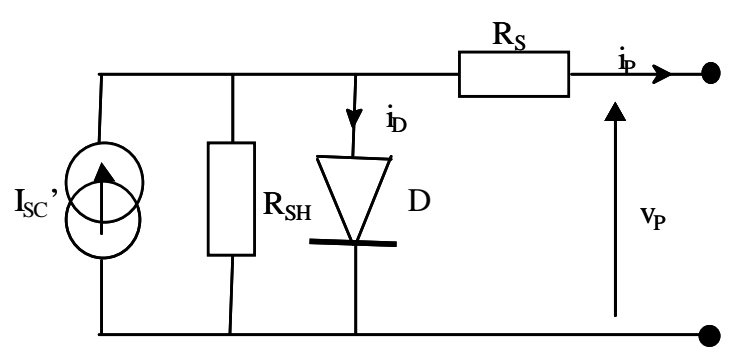

Fig. 2. Electrical equivalent circuit of a PV

Where $R_{S}, R_{S_{H}}, D, I_{S C}$, represent respectively, the equivalent serial resistor, the equivalent shunt resistor, the 
equivalent diode checking the Schotkley expression, the short circuit current.

In order to extract most energy, the operating points must be located in the knees of the curves. A simplified analytical expression [3] of the power produced for this kind of operating is given by the following expression (1).

$$
M P P \approx V_{O C} I_{S C} \frac{24}{25}\left(1-\frac{V_{O C}}{R_{S H} I_{S C}}\right)\left(1-\frac{n_{S} V_{T} \ln (25)}{V_{O C}}\right)\left(1-\frac{R_{S} I_{S C}}{V_{O C}}\right)
$$

Where $V_{O C}, n_{S}, V_{T}$, represent respectively, the open circuit voltage, the number of series-connected cells, the thermic voltage of a cell.

A simplified analytical expression of the relation between the thermic voltage and the short circuit current can be obtained by:

$$
\mathrm{V}_{\mathrm{OC}}(\mathrm{T}) \approx \mathrm{n}_{\mathrm{s}} \mathrm{V}_{\mathrm{T}}\left(\mathrm{T}_{0}\right) \frac{\mathrm{T}}{\mathrm{T}_{0}} \ln \left(\frac{\mathrm{I}_{\mathrm{SC}}}{\mathrm{n}_{\mathrm{p}} \mathrm{I}_{\mathrm{S}}\left(\mathrm{T}_{0}\right) \exp \left(\mathrm{k}\left(\mathrm{T}-\mathrm{T}_{0}\right)\right)}\right)
$$

Where $T_{0}, T, n_{p}, I_{s}, k$, represent respectively, the reference temperature in degree Kelvin, the operating temperature, the number of branchs of cells, the saturation current of the equivalent diode, an empirical constant.

Then, a relation between the electrical power and the global irradiance is obtained through the short-circuit current parameter considered proportional to the irradiance.

\section{Expression of the equivalent global irradiance, in absence of clouds, in function of the considered geographic place [4]}

Assuming the distance from the sun to earth is constant, the position of the sun can be specified using two coordinates as shown in figure 3.

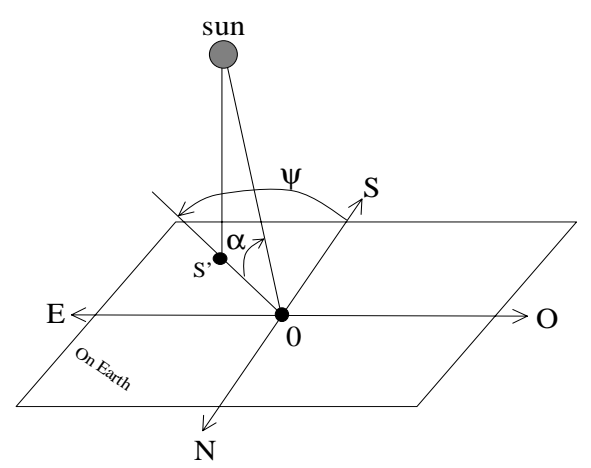

Fig. 3. Virtual position of the sun

The simplified equations of earth mechanics lead to the relations (3) :

$$
\begin{gathered}
\delta_{d}=23,45^{\circ} \sin (360(d-80) / 365) \\
\omega=360^{\circ}((12-h) / 24)
\end{gathered}
$$

$$
\begin{aligned}
& \alpha=\operatorname{Arcsin}\left\{\sin \left(\delta_{d}\right) \sin (\varphi)+\cos \left(\delta_{d}\right) \cos (\varphi) \cos (\omega)\right\} \\
& \psi=\operatorname{Arccos}\left[\frac{\sin (\alpha) \sin (\varphi)-\sin \left(\delta_{d}\right)}{\cos (\alpha) \cos (\varphi)}\right]
\end{aligned}
$$

where $\delta_{d}, d, \varphi, \omega, h, \alpha, \psi$, represent respectively, the declination angle of the sun, day of the year, the latitude of the considered geographic place, virtual angular displacement of the sun, the considered hour of day, the angle of solar altitude, the azimuth angle.

On a sunny day, a PV panel directly facing due South and tilted at an angle $\xi$ receives an incidence irradiance $\varepsilon$ as shown in figure 4.

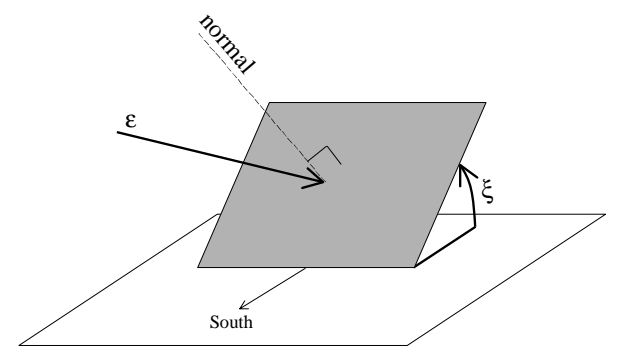

Fig. 4. Irradiance received by a tilted PV panel

The PV panels recovers an equivalent irradiance $\varepsilon_{N}$ which is normal to the surface of the panels. By neglecting the effect of the reflection on the surface of the panel, $\varepsilon_{N}$ value can be obtained by the scalar product of the direction of $\varepsilon$ and the normal on the surface of the panel as given by the expression (4):

$\varepsilon_{N}=\varepsilon[\sin (\xi) \cos (\alpha) \cos (\psi)+\cos (\xi) \sin (\alpha)]$

where $\varepsilon_{\mathrm{N}}, \varepsilon, \xi$, represent respectively, the equivalent global irradiance, the global irradiance, the tilted angle of the panel.

Figure 5 shows the evolution of the theoretical global irradiance, during a day, at ground level, for the 2 June in the city of Paris $\left(\xi=35^{\circ}\right)$.

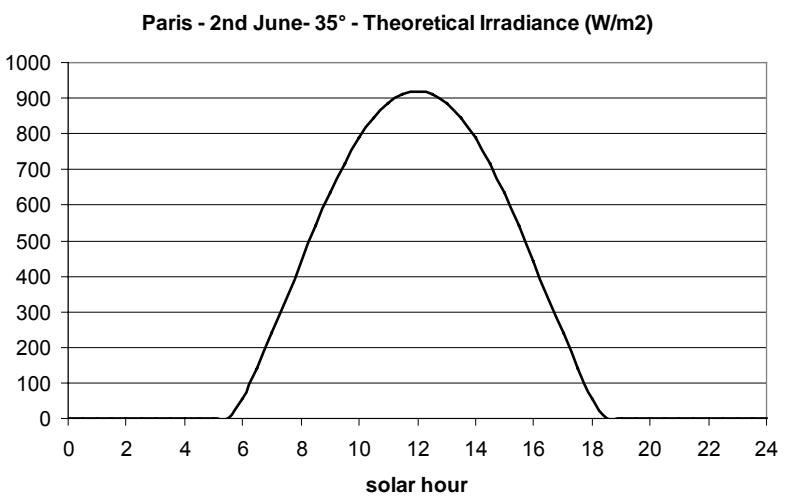

Fig. 5. Theoretical global irradiance

\section{Sky index}

Although theoretical irradiance is known by the formula (4), the panel receives this irradiance only in the absence of cloud. The attenuation of irradiance due to the presence of cloud will be taken into account in the form of a 
filtering factor. It is from statistical processing of the evolution of the density of cloud layers in versus time that the scenarios of the electrical power produced by a photovoltaic power system are elaborated.. In this paper, the databases are provided from Satel-Light [5] which covers western and central Europe. The layer of cloud is then defined in the form of an index, called Sky index in what follows, which can take 4 distinct values $(0,1,2,3)$. $\mathrm{SKY}=1$ sunny day; SKY=2 intermediate wheather, $\mathrm{SKY}=3$ cloudy; SKY=0 absence of irradiance (the night).

The figure 6 shows an example of monthly evolution of this index expressed in percentage, during the year, for the town of Paris.

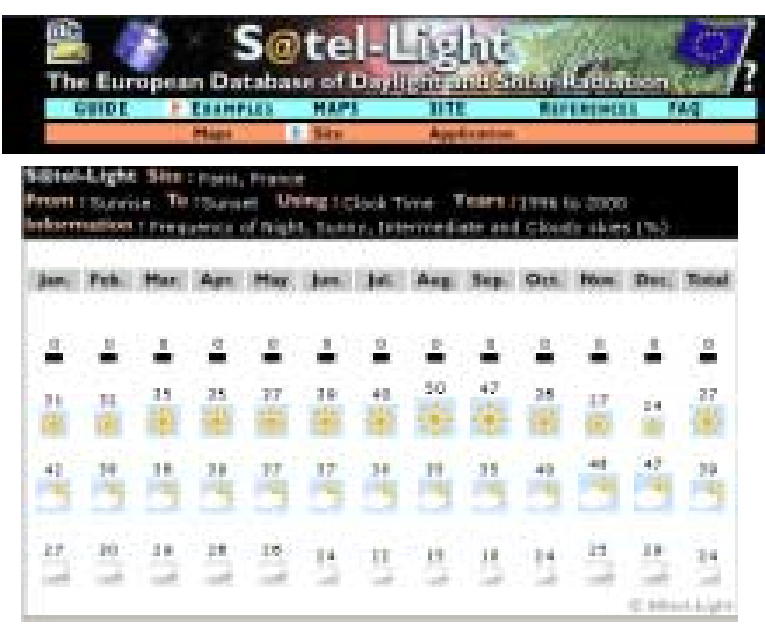

Fig. 6. example of SKY index frequency, for the city of Paris

\section{5. filtering factors due to the presence of clouds}

The following table I and figure 7 give the appearance frequency of the three following values of the sky index according to the month of the year.

TABLE. I. Monthly frequency of Sunny (S), Intermediate (I), and Cloudy (C) whearher - Strasbourg

\begin{tabular}{cccc}
\hline & Sunny & Intermediate & Cloudy \\
\hline jan & 23 & 42 & 35 \\
feb & 34 & 36 & 30 \\
mar & 38 & 29 & 33 \\
apr & 42 & 31 & 27 \\
may & 44 & 29 & 27 \\
jun & 46 & 31 & 23 \\
jul & 40 & 33 & 27 \\
aug & 53 & 29 & 18 \\
sep & 49 & 29 & 22 \\
oct & 28 & 43 & 29 \\
nov & 25 & 44 & 31 \\
dec & 16 & 51 & 33 \\
\hline Mean & 39 & 34 & 27 \\
\hline
\end{tabular}

Strasbourg - S, I and C

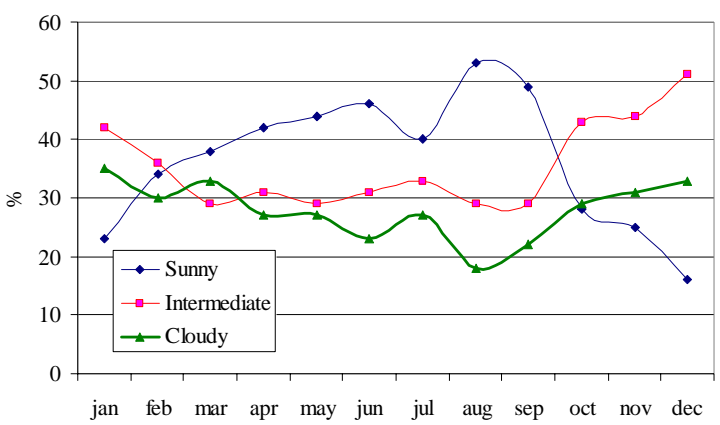

Fig. 7. Monthly frequency of Sunny (S), Intermediate (I), and Cloudy (C) whearher - Strasbourg

According to the 3 values of the SKY index, the irradiance collected by the PV module, will be more or less attenuated in comparison with the theoretical irradiance expression of Meinel and Meinel.

For each SKY index correspond a value of the filtering factor. This filtering factor is defined by the average ratio between the irradance collected by the PV module, and the theoretical value of the irradiance. These 3 ratios will be noted, $\mathrm{R}_{\mathrm{S}}$ (Sunny), $\mathrm{R}_{\mathrm{I}}$ (Intermediate), and $\mathrm{R}_{\mathrm{C}}$ (Cloudy). Under these conditions, the daily average value of the irradiation computed during a year is defined by (5):

$$
\mathrm{W}_{\text {estimated }}(\mathrm{m})=\mathrm{W}_{\text {theoretical }}(\mathrm{m})\left(\mathrm{S} / \mathrm{R}_{\mathrm{S}}+\mathrm{I} / \mathrm{R}_{\mathrm{I}}+\mathrm{C} / \mathrm{R}_{\mathrm{C}}\right)
$$

where $R_{S}, R_{I}$; and $R_{C}$ are the parameters to be identified and $\mathrm{W}_{\text {theoretical }}$ is the irradiation computed from the theoretical irradiance expression (4). $\mathrm{m}$ is the number of the considered month of the year.

By making the assumption that the real values of the irradiance collected by a PV panel during sunny days is close to the theoretical expression, the parameter $R_{S}$ is equal to 1 . The values of $R_{I}$ and $R_{C}$ are computed from the method of the least mean squares, by minimizing the difference as in (6) between the parameters $\mathrm{W}_{\text {estimated- }}$ daily $(m)$ and $\mathrm{W}_{\text {daily }}(\mathrm{m}) . \mathrm{W}_{\text {daily }}(\mathrm{m})$ represent the daily mean value of the irradiance mesured during a month by Satellight for the considered month.

$$
\sigma=\min \left(\sum_{\mathrm{m}=1}^{12}\left(\mathrm{~W}_{\text {daily }}(\mathrm{m})-\mathrm{W}_{\text {estimated-daily }}(\mathrm{m})\right)^{2}\right)
$$

By way of example in figure 8, for the city of Strasbourg, and for panels mounting on flat, the values of the filtering factors $R_{I}$ and $R_{C}$ are respectively 1.36 and 2.85 .

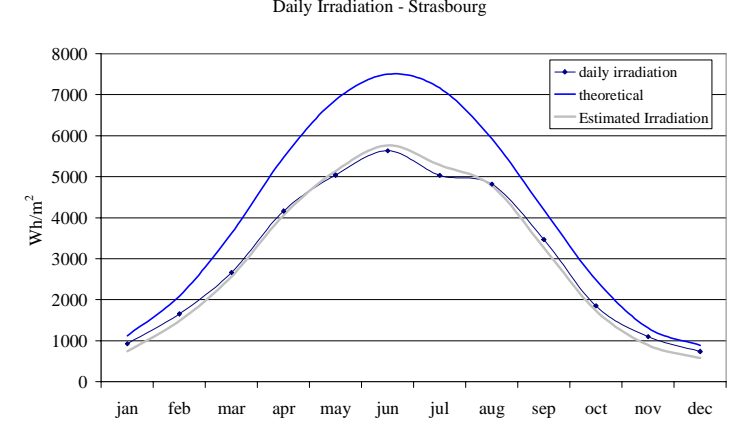

Fig. 8. Monthly Mean of daily sums of Global Horizontal Irradiation received by a PV panel - Strasbourg 
For the same mounting in Paris, the filtering factors are respectively $R_{I}=1.13$ and $R_{C}=3.67$. (as shown in figure 9).

Daily Irradiation - Paris

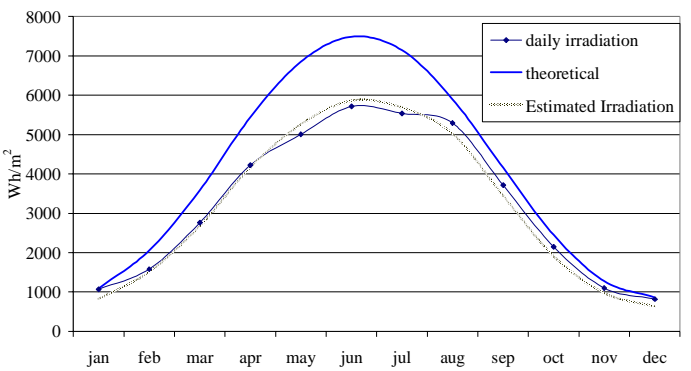

Fig. 9. Mean of daily sums of Global Horizontal Irradiation received by a PV panel - Paris

\section{Reconstitution of the irradiance in versus time}

Knowing the evolution of the SKY index in versus time, the irradiance is reconstituted from the theoretical irradiance expression and the filtering factors in accordance with the following algorithm:

$$
\begin{gathered}
\text { If } S K Y=1 \text {, then } R=R_{S} \text {, } \\
\text { if } S K Y=2 \text {, then } R=R_{I} \text {, } \\
\text { if } S K Y=3 \text {, then } R=R_{C} \text {, } \\
\varepsilon_{\text {stoch }}=\varepsilon_{\mathrm{N}} / \mathrm{R}
\end{gathered}
$$

where $\varepsilon_{\text {stoch }}$ is the reconstituted irradiance, as in figure 10 for the city of Paris with a $35^{\circ}$ tilted angle.

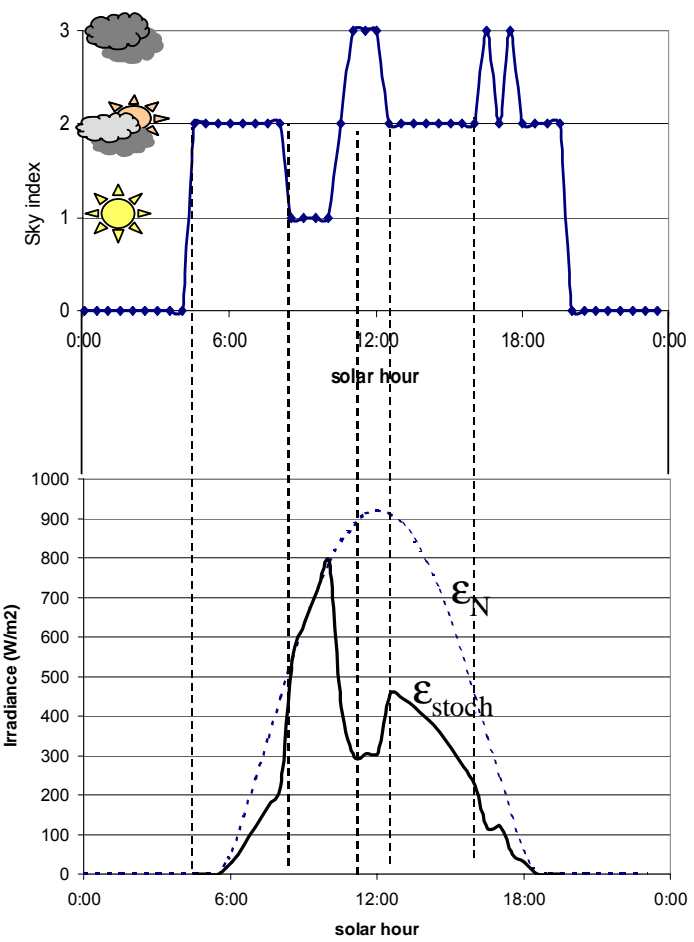

Fig. 10. Paris- The $2^{\text {nd }}$ Juin $1996-35^{\circ}$

\section{Probability density of variations of the sky index}

The observation of the changes of state of the Sky index between two successive time intervals lead to establish the following profiles of variation of the global irradiance as in table II :

TABLE II.- Variation profiles of the global irradiance.

Variation profiles of the global irradiance

Counting the appearances of these profiles through the last five years for the considered month permit to elaborate probability tables.

The table II shows for the cities of Paris and Madrid, the various frequencies of appearance of the profiles $P_{1}$ to $P_{5}$. The months appearing in the figure 11 , are respectively the months of equinoxes and solstices. The values of the occurrences are expressed in logarithmic scales.
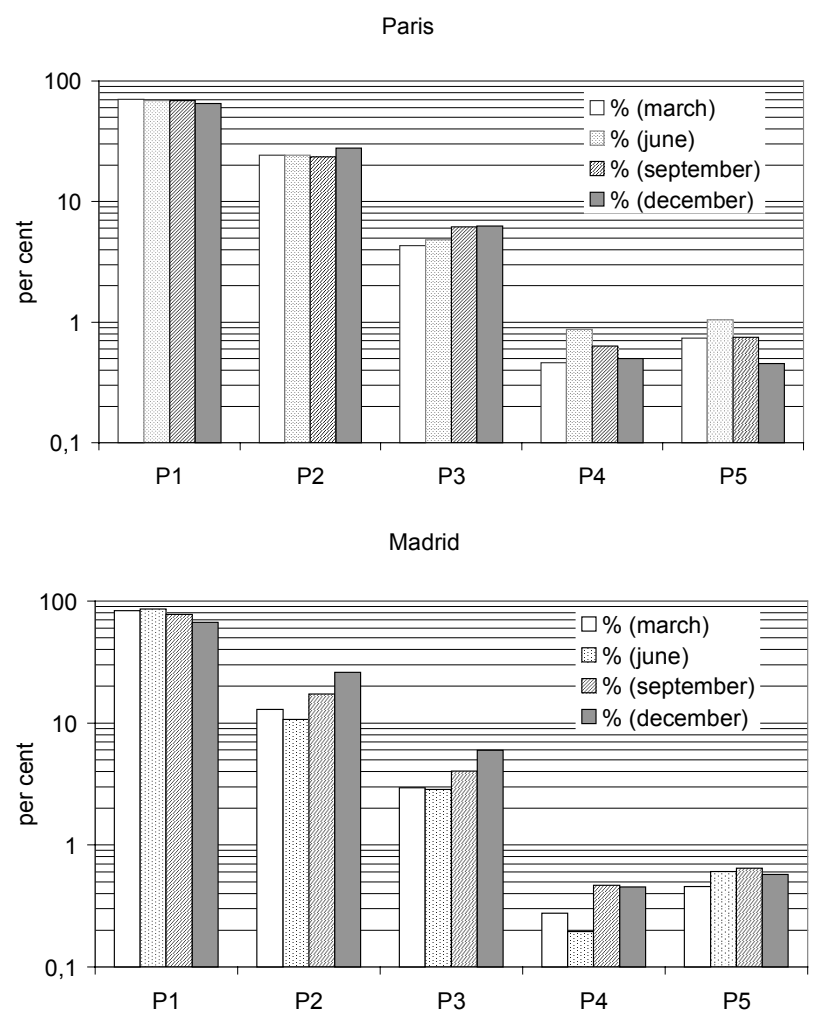

Fig. 11. Percentage of appearance of the different profiles

As shown in figure 11 , the profiles $\left(\mathrm{P}_{1}, \mathrm{P}_{2}, \mathrm{P}_{3}\right)$, which appear the most of time, are not very sensitive to the season. the appearance frequency of the profiles, varies softly according to the geographical place.

Consequently, the stochastic simulator presented in this article takes into account only the influence of the geographic place on the appearance values of the profiles which are given in table III. 
TABLE III.- Mean values of the profiles.

\begin{tabular}{|c|c|c|}
\hline Profiles & $\%$ Paris & $\%$ Madrid \\
\hline P1 & 68,28 & 78,42 \\
\hline P2 & 24,98 & 16,72 \\
\hline P3 & 5,38 & 3,95 \\
\hline P4 & 0,62 & 0,35 \\
\hline P5 & 0,75 & 0,57 \\
\hline
\end{tabular}

\section{Stochastic simulator of electrical power}

The real time stochastic simulator of the irradiance for a considered geographic place, requires the knowledge of eight specific parameters ( the probabilities of appearance of the five profiles $\mathrm{P}_{1}$ to $\mathrm{P}_{5}$, the three filtering factors associated to the SKY index $R_{I}, R_{C}, R_{S}$ ).

The statistic weights of each profiles are deduced from table IV.

TABLE IV.- Probabilities of appearance of each profiles

\begin{tabular}{|c|c|c|}
\hline Profiles & Past $\rightarrow$ Present $\rightarrow$ Future & Frequency \\
\hline \multirow[t]{3}{*}{$\mathrm{P}_{1}$} & $1 \rightarrow 1 \rightarrow 1$ & $\mathrm{~F}(1)=\mathrm{P} 1 * \mathrm{~S}$ \\
\hline & $2 \rightarrow 2 \rightarrow 2$ & $\mathrm{~F}(14)=\mathrm{P} 1 * \mathrm{I}$ \\
\hline & $3 \rightarrow 3 \rightarrow 3$ & $\mathrm{~F}(27)=\mathrm{P} 1 * \mathrm{C}$ \\
\hline \multirow[t]{8}{*}{$\mathrm{P}_{2}$} & $1 \rightarrow 1 \rightarrow 2$ & $\mathrm{~F}(2)=\mathrm{P} 2 * \mathrm{I}$ \\
\hline & $2 \rightarrow 2 \rightarrow 1$ & $\mathrm{~F}(13)=\mathrm{P} 2 * \mathrm{~S}$ \\
\hline & $2 \rightarrow 2 \rightarrow 3$ & $\mathrm{~F}(15)=\mathrm{P} 2 * \mathrm{C}$ \\
\hline & $3 \rightarrow 3 \rightarrow 2$ & $\mathrm{~F}(26)=\mathrm{P} 2 * \mathrm{I}$ \\
\hline & $1 \rightarrow 2 \rightarrow 2$ & $\mathrm{~F}(5)=\mathrm{P} 2 * \mathrm{I}$ \\
\hline & $2 \rightarrow 3 \rightarrow 3$ & $\mathrm{~F}(18)=\mathrm{P} 2 * \mathrm{C}$ \\
\hline & $3 \rightarrow 2 \rightarrow 2$ & $\mathrm{~F}(23)=\mathrm{P} 2 * \mathrm{I}$ \\
\hline & $2 \rightarrow 1 \rightarrow 1$ & $\mathrm{~F}(10)=\mathrm{P} 2 * \mathrm{~S}$ \\
\hline \multirow[t]{4}{*}{$\mathrm{P}_{3}$} & $1 \rightarrow 2 \rightarrow 1$ & $\mathrm{~F}(4)=\mathrm{P} 3 * \mathrm{~S}$ \\
\hline & $2 \rightarrow 1 \rightarrow 2$ & $\mathrm{~F}(11)=\mathrm{P} 3 * \mathrm{I}$ \\
\hline & $2 \rightarrow 3 \rightarrow 2$ & $\mathrm{~F}(17)=\mathrm{P} 3 * \mathrm{I}$ \\
\hline & $3 \rightarrow 2 \rightarrow 3$ & $\mathrm{~F}(24)=\mathrm{P} 3 * \mathrm{C}$ \\
\hline \multirow[t]{2}{*}{$\mathrm{P}_{4}$} & $1 \rightarrow 2 \rightarrow 3$ & $\mathrm{~F}(6)=\mathrm{P} 4 * \mathrm{C}$ \\
\hline & $3 \rightarrow 2 \rightarrow 1$ & $\mathrm{~F}(22)=\mathrm{P} 4 * \mathrm{~S}$ \\
\hline \multirow[t]{10}{*}{$\mathrm{P}_{5}$} & $2 \rightarrow 3 \rightarrow 1$ & $\mathrm{~F}(16)=\mathrm{P} 5 * \mathrm{~S}$ \\
\hline & $1 \rightarrow 3 \rightarrow 2$ & $\mathrm{~F}(8)=\mathrm{P} 5 * \mathrm{I}$ \\
\hline & $2 \rightarrow 1 \rightarrow 3$ & $\mathrm{~F}(12)=\mathrm{P} 5 * \mathrm{C}$ \\
\hline & $3 \rightarrow 1 \rightarrow 2$ & $\mathrm{~F}(20)=\mathrm{P} 5 * \mathrm{I}$ \\
\hline & $1 \rightarrow 1 \rightarrow 3$ & $\mathrm{~F}(3)=\mathrm{P} 5 * \mathrm{C}$ \\
\hline & $3 \rightarrow 1 \rightarrow 1$ & $F(19)=P 5 * S$ \\
\hline & $3 \rightarrow 3 \rightarrow 1$ & $F(25)=P 5 * S$ \\
\hline & $1 \rightarrow 3 \rightarrow 3$ & $\mathrm{~F}(9)=\mathrm{P} 5{ }^{*} \mathrm{C}$ \\
\hline & $3 \rightarrow 1 \rightarrow 3$ & $\mathrm{~F}(21)=\mathrm{P} 5 * \mathrm{C}$ \\
\hline & $1 \rightarrow 3 \rightarrow 1$ & $\mathrm{~F}(7)=\mathrm{P} 5 * \mathrm{~S}$ \\
\hline
\end{tabular}

Once the last index and the present index of sky are known, weights of probabylity are affected for each one of the next possible index. In table $\mathrm{V}$ are presented the probabilities of appearance of the next index deduced from the table IV.
TABLE V.

\begin{tabular}{|c|c|}
\hline Profiles & Weight \\
\hline 111 & $\mathrm{~W}(1)=\mathrm{F}(1) /(\mathrm{F}(1)+\mathrm{F}(2)+\mathrm{F}(3))$ \\
\hline 112 & $\mathrm{~W}(2)=\mathrm{F}(2) /(\mathrm{F}(1)+\mathrm{F}(2)+\mathrm{F}(3))$ \\
\hline 113 & $\mathrm{~W}(3)=\mathrm{F}(3) /(\mathrm{F}(1)+\mathrm{F}(2)+\mathrm{F}(3))$ \\
\hline 121 & $\mathrm{~W}(4)=\mathrm{F}(4) /(\mathrm{F}(4)+\mathrm{F}(5)+\mathrm{F}(6))$ \\
\hline 122 & $\mathrm{~W}(5)=\mathrm{F}(5) /(\mathrm{F}(4)+\mathrm{F}(5)+\mathrm{F}(6))$ \\
\hline 123 & $\mathrm{~W}(6)=\mathrm{F}(6) /(\mathrm{F}(4)+\mathrm{F}(5)+\mathrm{F}(6))$ \\
\hline 131 & $\mathrm{~W}(7)=\mathrm{F}(7) /(\mathrm{F}(7)+\mathrm{F}(8)+\mathrm{F}(9))$ \\
\hline 132 & $\mathrm{~W}(8)=\mathrm{F}(8) /(\mathrm{F}(7)+\mathrm{F}(8)+\mathrm{F}(9))$ \\
\hline 133 & $\mathrm{~W}(9)=\mathrm{F}(9) /(\mathrm{F}(7)+\mathrm{F}(8)+\mathrm{F}(9))$ \\
\hline 211 & $\mathrm{~W}(10)=\mathrm{F}(10) /(\mathrm{F}(10)+\mathrm{F}(11)+\mathrm{F}(12))$ \\
\hline 212 & $\mathrm{~W}(11)=\mathrm{F}(11) /(\mathrm{F}(10)+\mathrm{F}(11)+\mathrm{F}(12))$ \\
\hline 213 & $\mathrm{~W}(12)=\mathrm{F}(12) /(\mathrm{F}(10)+\mathrm{F}(11)+\mathrm{F}(12))$ \\
\hline 221 & $\mathrm{~W}(13)=\mathrm{F}(13) /(\mathrm{F}(13)+\mathrm{F}(14)+\mathrm{F}(15))$ \\
\hline 222 & $\mathrm{~W}(14)=\mathrm{F}(14) /(\mathrm{F}(13)+\mathrm{F}(14)+\mathrm{F}(15))$ \\
\hline 223 & $\mathrm{~W}(15)=\mathrm{F}(15) /(\mathrm{F}(13)+\mathrm{F}(14)+\mathrm{F}(15))$ \\
\hline 231 & $\mathrm{~W}(16)=\mathrm{F}(16) /(\mathrm{F}(16)+\mathrm{F}(17)+\mathrm{F}(18))$ \\
\hline 232 & $\mathrm{~W}(17)=\mathrm{F}(17) /(\mathrm{F}(16)+\mathrm{F}(17)+\mathrm{F}(18))$ \\
\hline 233 & $\mathrm{~W}(18)=\mathrm{F}(18) /(\mathrm{F}(16)+\mathrm{F}(17)+\mathrm{F}(18))$ \\
\hline 311 & $\mathrm{~W}(19)=\mathrm{F}(19) /(\mathrm{F}(19)+\mathrm{F}(20)+\mathrm{F}(21))$ \\
\hline 312 & $\mathrm{~W}(20)=\mathrm{F}(20) /(\mathrm{F}(19)+\mathrm{F}(20)+\mathrm{F}(21))$ \\
\hline 313 & $\mathrm{~W}(21)=\mathrm{F}(21) /(\mathrm{F}(19)+\mathrm{F}(20)+\mathrm{F}(21))$ \\
\hline 321 & $\mathrm{~W}(22)=\mathrm{F}(22) /(\mathrm{F}(22)+\mathrm{F}(23)+\mathrm{F}(24))$ \\
\hline 322 & $\mathrm{~W}(23)=\mathrm{F}(23) /(\mathrm{F}(22)+\mathrm{F}(23)+\mathrm{F}(24))$ \\
\hline 323 & $\mathrm{~W}(24)=\mathrm{F}(24) /(\mathrm{F}(22)+\mathrm{F}(23)+\mathrm{F}(24))$ \\
\hline 331 & $\mathrm{~W}(25)=\mathrm{F}(25) /(\mathrm{F}(25)+\mathrm{F}(26)+\mathrm{F}(27))$ \\
\hline 332 & $\mathrm{~W}(26)=\mathrm{F}(26) /(\mathrm{F}(25)+\mathrm{F}(26)+\mathrm{F}(27))$ \\
\hline 333 & $\mathrm{~W}(27)=\mathrm{F}(27) /(\mathrm{F}(25)+\mathrm{F}(26)+\mathrm{F}(27))$ \\
\hline
\end{tabular}

Then random numbers are carried out through the parameter ALEA. which belongs to the interval 0 and 1 . In table VI are defined 2 thresholds (Thr1 and Thr2) in order to obtain three intervals corresponding to the three SKY index.

If $0<\mathrm{ALEA} \leq \mathrm{Thr} 1$, then $\mathrm{SKY}=1$,

If $\mathrm{Thr} 1<\mathrm{ALEA} \leq \mathrm{Thr} 2$, then SKY=2,

If $\mathrm{Thr} 2<\mathrm{ALEA}$, then SKY=3.

Stochastic irradiance $\left(\varepsilon_{\text {stoch }}\right)$ is calculated in accordance with the algorithm presented at the figure 12 . 
TABLE VI.

\begin{tabular}{|c|c|c|}
\hline Past $\rightarrow$ Present & Next SKY index & Range of ALEA \\
\hline \multirow[t]{3}{*}{$1 \rightarrow 1$} & 1 & $0<\operatorname{ALEA} \leq \mathrm{W}(1)$ \\
\hline & 2 & $\mathrm{~W}(1)<\mathrm{ALEA} \leq \mathrm{W}(1)+\mathrm{W}(2)$ \\
\hline & 3 & $\mathrm{~W}(1)+\mathrm{W}(2)<\mathrm{ALEA}$ \\
\hline \multirow[t]{3}{*}{$1 \rightarrow 2$} & 1 & $0<\mathrm{ALEA} \leq \mathrm{W}(4)$ \\
\hline & 2 & $\mathrm{~W}(4)<\mathrm{ALEA} \leq \mathrm{W}(4)+\mathrm{W}(5)$ \\
\hline & 3 & $\mathrm{~W}(4)+\mathrm{W}(5)<\mathrm{ALEA}$ \\
\hline \multirow[t]{3}{*}{$1 \rightarrow 3$} & 1 & $0<\operatorname{ALEA} \leq \mathrm{W}(7)$ \\
\hline & 2 & $\mathrm{~W}(7)<\mathrm{ALEA} \leq \mathrm{W}(7)+\mathrm{W}(8)$ \\
\hline & 3 & $\mathrm{~W}(7)+\mathrm{W}(8)<\mathrm{ALEA}$ \\
\hline \multirow[t]{3}{*}{$2 \rightarrow 1$} & 1 & $0<\operatorname{ALEA} \leq \mathrm{W}(10)$ \\
\hline & 2 & $\mathrm{~W}(10)<\mathrm{ALEA} \leq \mathrm{W}(10)+\mathrm{W}(11)$ \\
\hline & 3 & $\mathrm{~W}(10)+\mathrm{W}(11)<\mathrm{ALEA}$ \\
\hline \multirow[t]{3}{*}{$2 \rightarrow 2$} & 1 & $0<\mathrm{ALEA} \leq \mathrm{W}(13)$ \\
\hline & 2 & $\mathrm{~W}(13)<\mathrm{ALEA} \leq \mathrm{W}(13)+\mathrm{W}(14)$ \\
\hline & 3 & $\mathrm{~W}(13)+\mathrm{W}(13)<\mathrm{ALEA}$ \\
\hline \multirow[t]{3}{*}{$2 \rightarrow 3$} & 1 & $0<\operatorname{ALEA} \leq \mathrm{W}(16)$ \\
\hline & 2 & $\mathrm{~W}(16)<\mathrm{ALEA} \leq \mathrm{W}(16)+\mathrm{W}(17)$ \\
\hline & 3 & $\mathrm{~W}(16)+\mathrm{W}(17)<\mathrm{ALEA}$ \\
\hline \multirow[t]{3}{*}{$3 \rightarrow 1$} & 1 & $0<\operatorname{ALEA} \leq \mathrm{W}(19)$ \\
\hline & 2 & $\mathrm{~W}(19)<\mathrm{ALEA} \leq \mathrm{W}(19)+\mathrm{W}(20)$ \\
\hline & 3 & $\mathrm{~W}(19)+\mathrm{W}(20)<\mathrm{ALEA}$ \\
\hline \multirow[t]{3}{*}{$3 \rightarrow 2$} & 1 & $0<\mathrm{ALEA} \leq \mathrm{W}(22)$ \\
\hline & 2 & $\mathrm{~W}(22)<\mathrm{ALEA} \leq \mathrm{W}(22)+\mathrm{W}(21)$ \\
\hline & 3 & $\mathrm{~W}(22)+\mathrm{W}(21)<\mathrm{ALEA}$ \\
\hline \multirow[t]{3}{*}{$3 \rightarrow 3$} & 1 & $0<\operatorname{ALEA} \leq \mathrm{W}(25)$ \\
\hline & 2 & $\mathrm{~W}(25)<\mathrm{ALEA} \leq \mathrm{W}(25)+\mathrm{W}(26)$ \\
\hline & 3 & $\mathrm{~W}(25)+\mathrm{W}(26)<\mathrm{ALEA}$ \\
\hline
\end{tabular}

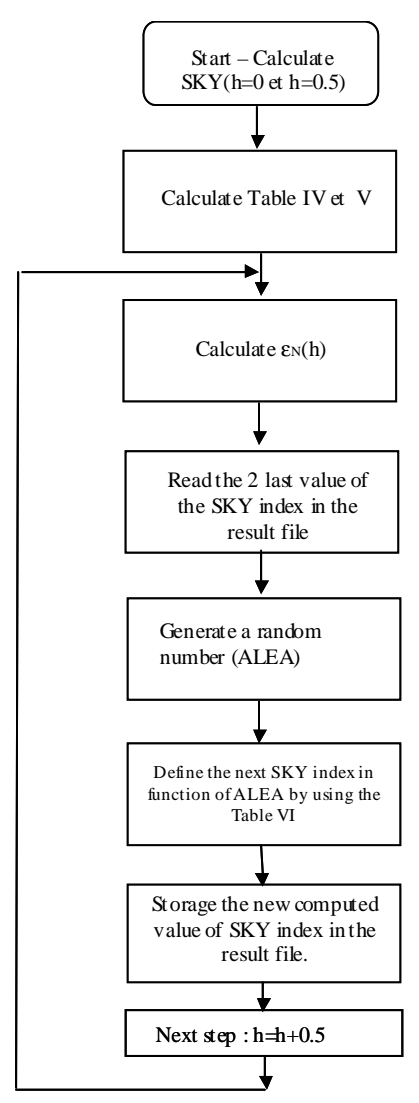

Fig. 12. Stochastic generator.

\section{Example of simulation}

A scenario of production of electrical energy in versus time is built up starting from the probability tables of the variations of the global irradiance. Then the electrical power is deduced from the equation 1 through the irradiance parameter. The figure 13 shows a possible scenario of evolution of the power produced during the month of June by an installation of $3 \mathrm{kWp}$ installed in Paris, facing to south, tilted with an optimal angle of $30^{\circ}$.

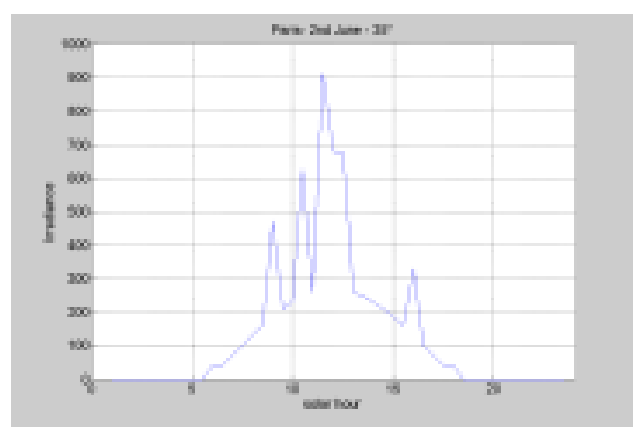

Fig. 13. Electrical power produced in a cloudy day

The example relates to the city of Paris for a slope of $0^{\circ}$, June 15 . The generator daily irradiation is the mean value computed on 100 samples.

The Satel-light value is a month daily mean June value. The variation is lower than 5\%. The Stochastic generator gives $5480 \mathrm{Wh} / \mathrm{m}^{2}$ and the Satel-light value is 5712 $\mathrm{Wh} / \mathrm{m}^{2}$.

The computed values are in conformity with the standard conditions from a statistical point of view. The results are acceptable when the error is less than $30 \%$.

\section{Conclusion}

The generation of credible scenarios need a relatively weak computing time with the traditional simulation tools . It is particularly well adapted to the calculation of load flows and voltage drops in the low voltage electrical networks. The methode can also be adapted to the production of electrical energy produced by wind turbines.

\section{Acknowledgement}

This work is part of project 'Futurelec 1' within 'Centre National de Recherche Technologique (CNRT) of Lille' The support of the CNRT (Région Nord Pas de Calais, the FEDER, the FRT) is kindly acknowledged.

\section{References}

[1] Hiroshi Matsukawa, Koukichi Koshiishi, 'Dynamic evaluation of maximum power point tracking operation with PV array simulator, Solar Energy Materials \& Solar Cells 75, pp537-546, NH ELSEVIER, 2003.

[2] Stirn RJ., Junction characteristics of a silicon solar cells. In : $9^{\text {th }}$ IEEE Photovoltaic Specialists Conference, 1972, pp 72-82.

[3] V. Autier V. Molcrette, H. Roisse'Determination of the parameters of equivalent electrical model of photovoltaic module (PV). Application to the maximal power point (MPP) analytical expression.'. ICREPQ'03- CD rom Vigo 9-12 April 2003.

[4] Photovoltaic systems engineering. Roger Messenger, Jerry Ventre. Electrical Engineering/ Power Engineering/ Energy Systems.

[5] Satel-Light, the European daylight and solar radiation database (http://www.satel-light.com, e-mail: webmaster@satellight.com). 